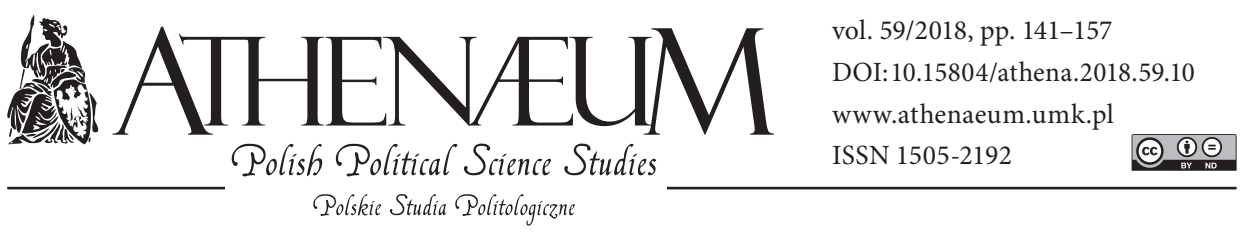

\title{
THE IMPACT OF BREXIT AND THE NEW LEGAL FRAMEWORK FOR EUROPEAN STATISTICS IN DEMOGRAPHY ON THE VOTING POWER OF POLAND IN THE COUNCIL OF THE EUROPEAN UNION*
}

\author{
WPŁYW BREXITU I NOWYCH RAM PRAWNYCH \\ W ZAKRESIE STATYSTYK EUROPEJSKICH W DZIEDZINIE \\ DEMOGRAFII NA SIŁĘ GŁOSU POLSKI W RADZIE UE
}

Marcin Kleinowski**

\begin{abstract}
The article analyses the potential impact of Brexit and the new legal framework for European statistics in demography on the formal voting power of Poland in the Council of the European Union, in the case of adopting decisions by the qualified majority of votes. The leading hypothesis of the paper assumes that the fact of leaving the European Union by Great Britain and the new method of determining the population of EU Member States for the purposes of making decisions in the Council of the European Union leads to another transfer of formal voting power to the benefit of countries with the largest populations, as well as reduces the ability of Poland to build strictly minimally blocking coalitions, in
\end{abstract}

\begin{abstract}
ABSTRAKT
Artykuł analizuje potencjalny wpływ brexitu oraz nowych ram prawnych w zakresie statystyk europejskich w dziedzinie demografii na formalną siłę głosu Polski w Radzie UE w przypadku podejmowania decyzji kwalifikowaną większością głosów. Hipoteza przewodnia pracy zakłada, że wystąpienie Wielkiej Brytanii z Unii Europejskiej oraz wprowadzenie nowego sposobu określania liczby ludności państw członkowskich UE dla potrzeb podejmowania decyzji w Radzie prowadzi do kolejnego przepływu formalnej siły głosu na rzecz krajów o największej populacji, jak również zmniejsza zdolność Polski do budowania koalicji ściśle minimalnych blokujących, a w szczególno-
\end{abstract}

* Nicolaus Copernicus University in Toruń, Faculty of Political Sciences and International Studies. ORCID: https://orcid.org/0000-0003-4613-5886.

** Presented research is founded by National Science Centre in Poland under the project no. UMO-2016/23/D/HS5/00408 (SONATA 12 grant) entitled: The Impact of Brexit and Unconditional Introduction of the 'Double Majority' Voting System on Decision-Making in the Council of the European Union. 
particular in opposition to the coalition being formed by France and Germany or the so-called "Trio of Ventotene".

Keywords: Council of the European Union, voting power, Brexit, blocking coalitions ści w opozycji do koalicji tworzonej przez Niemcy i Francję lub tzw. trójkę z Ventotene.

Słowa kluczowe: Rada Unii Europejskiej, siła głosu, brexit, koalicje blokujące

The population of the European Union (EU) Member States is one of the many factors influencing their position in the Council, and in particular their formal voting power. In the Nice voting system, the population criterion was optional, whereas in the double majority system it is mandatory ${ }^{1}$. The Treaty of Lisbon extended the scope of decisions adopted in the Council by a qualified majority ${ }^{2}$, as well as, under Article 16(3) of the Treaty on European Union, it made this voting procedure default for that institution, except in cases where treaties provide otherwise. Thus, it increased the importance of the way of weighting the votes as one of the factors affecting the power of a state in the EU. It should be borne in mind that it also affects the way of aggregating interests by the Agenda setters, and in particular the European Commission. As a result of the introduction of the so-called double majority weighted voting system in the Council, there was a significant flow of voting power towards the four biggest states, and it became decisively more difficult to build blocking coalitions (Kleinowski, 2014, pp. 181-186).

Following the entry into force of the provisions of the Treaty of Lisbon, the culture of compromise in the EU Council begins to evolve (Kleinowski, 2013 , pp. 15-28), its direction points to the growing role of the formal vot-

1 In the double majority system, when a decision in the Council is adopted on the initiative of the European Commission or the High Representative of the Union for Foreign Affairs and Security Policy, a qualified majority constitutes at least $55 \%$ of the members of the Council representing the participating Member States, the total population of which is at least $65 \%$ of the population of these countries. At the same time, a blocking minority includes the minimum number of Council members representing more than $35 \%$ of the population of participating states, plus one additional member. The Treaty on European Union, Article 16(3); the Treaty on the Functioning of the European Union, Article 238(2).

2 The Treaty of Lisbon increased the scope of qualified majority voting by 51 articles and sub-articles (Miller \& Taylor, 2008, pp. 76-85). Only 50 articles and sub-articles were mentioned there, to which Article 45(2) of the consolidated version of the Treaty on European Union - the Rules for the Functioning of the European Defence Agency, should be added. 
ing power of the Member States in negotiations conducted on the forum of this institution. In the case of decisions adopted by qualified majority voting, objections or abstentions by states unable to block a decision are considered, by co-decision-makers, excessive and contradictory to the prevailing political culture. There is also an informal rule according to which, under the ordinary legislative procedure, the whole Council should defend the common position reached in this institution before the members of the European Parliament (Novak, 2011, pp. 18-19).

The aim of the article is to analyse the influence of Brexit and the new way of determining the population of EU Member States on Poland's formal voting power. In addition to the analysis of a priori voting, a methodologically innovative solution was used in this paper, which consists in departing from the assumption that the occurrence of all coalitions is equally probable. To this end, an original research tool was developed in the form of the POWERGEN 3.0 program, which makes it possible to carry out simulations of voting in the Council.

\section{THE STUDY OBJECTIVE AND THE RESEARCH TECHNIQUES AND TOOLS APPLIED}

The subject matter of the study is the weighted voting system in the Council and its impact on the formal voting power of the Member States. The object of the analysis is, therefore, a priori voting power, i.e., the component of the general power of a state which results exclusively from the voting rule in force. Thus, it identifies the chance of influencing the outcome of the decision-making process by a given entity or entities, taking into account only the voting rule understood as a strictly defined procedure of making decisions by vote by a committee composed of a number of members (Laruelle \& Valenciano, 2005, p. 173). A priori voting power should not be identified with the actual power of a state in the decision-making process in the EU, which is largely dependent on the decision situation and may not be reduced merely to the formal rules of proceeding.

The guiding hypothesis assumes that the fact of leaving the EU by Great Britain and the introduction of a new legal framework for European statistics will have a negative impact on Poland's formal voting power in the Council. There will be a transfer of voting power to the benefit of the countries with the largest populations, and it will be more difficult to block decisions adopted by qualified majority. 
In order to verify the main hypothesis, it will be necessary to examine several detailed hypotheses:

1. The new legal framework for European statistics increases the voting power of states with significant positive net migration and deepens the deficit of democracy in the EU.

2. The increase in Poland's formal voting power (as measured by the Normalized Banzhaf Index and the Preventive Power Index) as a result of Great Britain's leaving the EU is relatively small compared to the three largest Member States and, in the case of the ability to block decisions, illusory.

3. Brexit will make it difficult for Poland to form small strictly minimally blocking coalitions in the Council with a small number of members.

The research was conducted on the basis of the cooperative game theory and, in particular, weighted voting games in which the studied entities (players) have a certain number of votes, and controlling a sufficient number of them by a coalition of players provides an opportunity to accept or reject the proposed initiative.

Mathematical power indices were used to determine the change in the voting power of the Member States in the Council. Achieving the set research objective and verifying part of the hypotheses requires a departure from the widely adopted Bernoulli model, and in particular the assumption that in the case of each player casting a vote "for" or "against" an initiative is equally likely, and that they make decisions on how to vote independently of one another. A consequence of the methodological choices was the need to create a new research tool, as the existing solutions did not allow the departure from the Bernoulli model. The author developed the POWERGEN 3.0 program, which generates indices of the players' voting power on the assumption that the position that will be taken by part of co-decision-makers in the vote is already known and pre-determined.

Two mathematical power indices were used in the work. The Normalized Banzhaf Index (NBI) indicates what is the probability of a state becoming a pivotal player, and thus finding itself in a situation where its decision will determine whether a proposal will be accepted or rejected (Banzhaf, 1965). On the other hand, the Power to Prevent (Block) Action Index (PPI) indicates what is the chance of blocking a decision by a player. It is equal to the ratio of the number of winning coalitions in which player (state) is a swing member to the total number of winning coalitions (Coleman, 1971, pp. 204-206). 


\section{THE DEMOCRATICITY OF THE WEIGHTED VOTING SYSTEM} IN THE COUNCIL

The Regulation of the European Parliament and of the Council on demographic statistics in Europe has normalized the way of measuring the population of individual EU Member States for the needs of qualified majority voting in the Council. This change influences the formal voting power of the states in this institution, shaping their ability not only to force through or block decisions, but also the chance to attain the position of the so-called key player for the success of the initiative proposed by the European Commission. According to the aforementioned regulation, each Member State is required to submit to the European Commission (specifically Eurostat) data on the total population at national level within eight months of the end of the reference year, i.e., as at 31 December of that year. This should be construed as all persons residing in the state at the time of reference. In practice, this means that the population of a country takes into account not only its citizens, but also citizens of other EU Member States residing in that country, as well as non-EU citizens. It can, therefore, not be considered that the above solution strengthens the democratic legitimacy of the decision-making process in the EU, because in democratic systems the right to participate in the election of central authorities is only held by citizens. As a result, the adopted solution creates in the public reception an illusion of the democratic legitimacy of decisions adopted in the Council. It should be emphasized that the states the representatives of which act on behalf of and to the benefit of citizens of those Member States, irrespective of their current place of residence, are represented in the Council. The problem of taking into account non-citizens in determining the weighting power of states in the Council occurs in both the double majority and the Nice systems. In the case of the latter, however, it is of marginal importance as it is the criterion of weighted votes that exerts the greatest influence on the formal voting power of Member States in the Nice weighted voting system ${ }^{3}$.

The method of measuring the population of Member States in force under Art. 4 sec. 1 of Regulation (EU) No. 1260/2013 of the European Parliament and of the Council of 20 November 2013 on European Statistics in the field of demography, is favourable primarily to countries from the so-called "old fifteen" where, as

3 In the Nice weighted voting system, only 423 out of 5,032,534 coalitions meeting the weighted vote criterion do not reach the threshold of the majority of states, or $62 \%$ of the EU population. 
indicated in Table 1, the proportion of immigrants in the population is relatively higher. In the case of Germany and Spain, this is over 9\% of the population, in Italy and in the United Kingdom over $8 \%$, and in Poland only $0.25 \%$. Luxembourg has the largest share of non-citizens in the population of a Member State, accounting for almost $46 \%$ of its population.

Table 1. Population of non-citizens residing in individual EU Member States

\begin{tabular}{|c|c|c|c|c|}
\hline State & Population & $\begin{array}{c}\text { Number of } \\
\text { non-citizens in } \\
\text { a given state }\end{array}$ & $\begin{array}{l}\text { Number of non- } \\
\text {-EU citizens }\end{array}$ & $\begin{array}{l}\text { Share of non- } \\
\text {-citizens in the } \\
\text { population }\end{array}$ \\
\hline Germany & 81089331 & 7539774 & 4055321 & $9,30 \%$ \\
\hline France & 66352469 & 4355707 & 2869882 & $6,56 \%$ \\
\hline $\begin{array}{c}\text { United } \\
\text { Kingdom }\end{array}$ & 64767115 & 5422094 & 2434022 & $8,37 \%$ \\
\hline Italy & 61438480 & 5014437 & 3521825 & $8,16 \%$ \\
\hline Spain & 46439864 & 4454354 & 2505196 & $9,59 \%$ \\
\hline Poland & 38005614 & 108279 & 76595 & $0,28 \%$ \\
\hline Romania & 19861408 & 88771 & 54687 & $0,45 \%$ \\
\hline Netherlands & 17155169 & 773288 & 338773 & $4,51 \%$ \\
\hline Belgium & 11258434 & 1300493 & 442752 & $11,55 \%$ \\
\hline Greece & 10846979 & 821969 & 623246 & $11,99 \%$ \\
\hline Czech Rep. & 10419743 & 457323 & 272993 & $3,79 \%$ \\
\hline Portugal & 10374822 & 395195 & 294778 & $4,41 \%$ \\
\hline Hungary & 9855571 & 145727 & 64821 & $1,48 \%$ \\
\hline Sweden & 9790000 & 731215 & 416246 & $7,47 \%$ \\
\hline Austria & 8581500 & 1131164 & 562850 & $13,18 \%$ \\
\hline Bulgaria & 7202198 & 65622 & 51246 & $0,91 \%$ \\
\hline Denmark & 5653357 & 422492 & 244380 & $7,47 \%$ \\
\hline Finland & 5471753 & 218803 & 127792 & $1,13 \%$ \\
\hline Slovakia & 5403134 & 61766 & 13064 & $4,05 \%$ \\
\hline Ireland & 4625885 & 550555 & 180219 & $11,90 \%$ \\
\hline Croatia & 4225316 & 36679 & 24218 & $0,87 \%$ \\
\hline Lithuania & 2921262 & 22470 & 16573 & $0,77 \%$ \\
\hline Slovenia & 2062874 & 101532 & 84367 & $4,92 \%$ \\
\hline Latvia & 1986096 & 298433 & 291440 & $15,03 \%$ \\
\hline Estonia & 1313271 & 191317 & 183415 & $14,57 \%$ \\
\hline
\end{tabular}




\begin{tabular}{|c|c|c|c|c|}
\hline State & Population & $\begin{array}{c}\text { Number of } \\
\text { non-citizens in } \\
\text { a given state }\end{array}$ & $\begin{array}{c}\text { Number of non- } \\
\text {-EU citizens }\end{array}$ & $\begin{array}{c}\text { Share of non- } \\
\text {-citizens in the } \\
\text { population }\end{array}$ \\
\hline Cyprus & 847008 & 144599 & 38242 & $17,07 \%$ \\
\hline Luxembourg & 562958 & 258679 & 36429 & $45,95 \%$ \\
\hline Malta & 429344 & 27476 & 12558 & $6,40 \%$ \\
\hline$\Sigma$ & 508940955 & 35140213 & 19837930 & $6,90 \%$ \\
\hline
\end{tabular}

Source: Own calculations based on: Council Decision (EU, Euratom) 2015/2393 of 8 December 2015 Amending the Council's Rules of Procedure; Eurostat, Population Without the Citizenship of the Reporting Country [last update: 1.01.2015], retrieved from: http://ec.europa.eu/eurostat/tgm/refreshTableAction.do?tab=table\&plugin $=1 \&$ pcode $=$ tps00157\&language $=$ en [access date: 30.09 .2016 ]; Eurostat, Population on 1 January by Five Year Age Group, Sex and Citizenship, retrieved from: http://appsso. eurostat.ec.europa.eu/nui/submitViewTableAction.do [access date: 30.09.2016].

The adopted solution also hinders the reliable determination of the populations living in individual Member States, in view of the significant migration movements of populations in the EU, including in particular external migration. It is likely that the same persons may be included in the population of more than one state. While in the face of high population mobility state authorities may find it difficult to reliably determine the number of the population residing at present on their territory, it should not be difficult to reliably determine the number of their own citizens. The problem with persons-citizens of more than one Member State is marginal and can be easily resolved.

It should also be noted that EU Member States are represented both in the Council and in the European Council, hence the population of these countries should be defined rather as the total number of citizens of those Member States. On the other hand, the solution introduced in this regard by Regulation No. $1260 / 2013$ could apply to the allocation of seats in the European Parliament between Member States, assuming that only EU citizens are taken into account.

\section{THE CHANGE OF THE FORMAL VOTING POWER OF MEMBER STATES IN THE COUNCIL FOR DECISIONS ADOPTED BY THE QUALIFIED MAJORITY OF VOTES}

As a result of the United Kingdom's withdrawal from the EU, the formal voting power in the Council will have increased first of all in the case of the five Member States with the largest populations. As indicated in Table 2 and Chart 1, in the 
case of the voting power measured using the Normalized Banzhaf Index, the position of Germany, France, Italy, Spain and Poland will be generally strengthened, whereby the volume of the voting power flow towards them is similar. As a consequence, for the adoption of an initiative proposed in the Council, it will be even more important to gain the support of the five states with the largest populations. A slight increase in voting power will be also observed in other Member States with populations of more than 5,400,000.

Table 2. Change in the voting power of the Member States when adopting decisions by the qualified majority of votes (measured by the Normalized Banzhaf Index and the Preventive Power Index) following the UK's withdrawal from the EU

\begin{tabular}{|c|c|c|c|c|c|c|c|c|}
\hline \multirow{2}{*}{ State } & \multicolumn{2}{|c|}{ EU 28 states } & \multicolumn{2}{|c|}{$\begin{array}{c}\text { EU 27 states } \\
\text { after Brexit }\end{array}$} & \multicolumn{3}{|c|}{ Change relative to EU 28 states } \\
\cline { 2 - 10 } & $\begin{array}{c}\text { NBI } \\
(\%)\end{array}$ & PPI (\%) & $\begin{array}{c}\text { NBI } \\
(\%)\end{array}$ & PPI (\%) & $\begin{array}{c}\text { NBI } \\
(\%)\end{array}$ & $\begin{array}{c}\text { Change in } \\
\text { percentage } \\
\text { points }\end{array}$ & $\begin{array}{c}\text { NBI } \\
(\%)\end{array}$ & $\begin{array}{c}\text { Change in } \\
\text { percentage } \\
\text { points }\end{array}$ \\
\hline Germany & 10,19 & 74,44 & 11,89 & 78,45 & 1,70 & $2,28 \%$ & 4,01 & $5,11 \%$ \\
\hline France & 8,45 & 61,68 & 9,96 & 65,67 & 1,51 & $15,15 \%$ & 3,99 & $6,07 \%$ \\
\hline United Kingdom & 8,27 & 60,37 & 1 & 1 & 1 & 1 & 1 & 1 \\
\hline Italy & 7,91 & 57,79 & 9,25 & 61,02 & 1,34 & $14,45 \%$ & 3,23 & $5,30 \%$ \\
\hline Spain & 6,20 & 45,28 & 7,66 & 50,50 & 1,46 & $19,00 \%$ & 5,22 & $10,34 \%$ \\
\hline Poland & 5,07 & 37,04 & 6,54 & 43,13 & 1,47 & $22,42 \%$ & 6,09 & $14,11 \%$ \\
\hline Romania & 3,78 & 27,62 & 4,01 & 26,42 & 0,22 & $5,57 \%$ & $-1,20$ & $-4,54 \%$ \\
\hline Netherlands & 3,50 & 25,54 & 3,70 & 24,42 & 0,20 & $5,53 \%$ & $-1,12$ & $-4,58 \%$ \\
\hline Belgium & 2,90 & 21,16 & 3,02 & 19,89 & 0,12 & $3,92 \%$ & $-1,27$ & $-6,36 \%$ \\
\hline Greece & 2,86 & 20,85 & 2,97 & 19,57 & 0,11 & $3,75 \%$ & $-1,28$ & $-6,55 \%$ \\
\hline Czech Rep. & 2,81 & 20,54 & 2,92 & 19,24 & 0,10 & $3,56 \%$ & $-1,30$ & $-6,76 \%$ \\
\hline Portugal & 2,81 & 20,50 & 2,91 & 19,20 & 0,10 & $3,54 \%$ & $-1,30$ & $-6,78 \%$ \\
\hline Hungary & 2,76 & 20,12 & 2,85 & 18,79 & 0,09 & $3,30 \%$ & $-1,32$ & $-7,05 \%$ \\
\hline Sweden & 2,75 & 20,07 & 2,84 & 18,74 & 0,09 & $3,27 \%$ & $-1,33$ & $-7,08 \%$ \\
\hline Austria & 2,63 & 19,17 & 2,70 & 17,79 & 0,07 & $2,66 \%$ & $-1,38$ & $-7,76 \%$ \\
\hline Bulgaria & 2,49 & 18,15 & 2,53 & 16,70 & 0,05 & $1,84 \%$ & $-1,45$ & $-8,66 \%$ \\
\hline Denmark & 2,33 & 17,00 & 2,35 & 15,48 & 0,02 & $0,82 \%$ & $-1,52$ & $-9,79 \%$ \\
\hline Finland & 2,31 & 16,86 & 2,33 & 15,34 & 0,02 & $0,69 \%$ & $-1,53$ & $-9,94 \%$ \\
\hline Slovakia & 2,30 & 16,81 & 2,32 & 15,29 & 0,01 & $0,64 \%$ & $-1,53$ & $-10,00 \%$ \\
\hline Ireland & 2,22 & 16,24 & 2,22 & 14,67 & 0,00 & $0,01 \%$ & $-1,57$ & $-10,69 \%$ \\
\hline
\end{tabular}




\begin{tabular}{|c|c|c|c|c|c|c|c|c|}
\hline \multirow{2}{*}{ State } & \multicolumn{2}{|c|}{ EU 28 states } & \multicolumn{2}{c|}{$\begin{array}{c}\text { EU 27 states } \\
\text { after Brexit }\end{array}$} & \multicolumn{3}{|c|}{ Change relative to EU 28 states } \\
\cline { 2 - 9 } & $\begin{array}{c}\text { NBI } \\
(\%)\end{array}$ & PPI (\%) & $\begin{array}{c}\text { NBI } \\
(\%)\end{array}$ & PPI (\%) & $\begin{array}{c}\text { NBI } \\
(\%)\end{array}$ & $\begin{array}{c}\text { Change in } \\
\text { percentage } \\
\text { points }\end{array}$ & $\begin{array}{c}\text { NBI } \\
(\%)\end{array}$ & $\begin{array}{c}\text { Change in } \\
\text { percentage } \\
\text { points }\end{array}$ \\
\hline Croatia & 2,18 & 15,94 & 2,18 & 14,35 & $-0,01$ & $-0,33 \%$ & $-1,59$ & $-11,06 \%$ \\
\hline Lithuania & 2,05 & 14,97 & 2,02 & 13,32 & $-0,03$ & $-1,54 \%$ & $-1,65$ & $-12,40 \%$ \\
\hline Slovenia & 1,96 & 14,32 & 1,91 & 12,63 & $-0,05$ & $-2,46 \%$ & $-1,70$ & $-13,42 \%$ \\
\hline Latvia & 1,95 & 14,27 & 1,91 & 12,57 & $-0,05$ & $-2,55 \%$ & $-1,70$ & $-13,52 \%$ \\
\hline Estonia & 1,88 & 13,76 & 1,82 & 12,03 & $-0,06$ & $-3,36 \%$ & $-1,73$ & $-14,42 \%$ \\
\hline Cyprus & 1,84 & 13,41 & 1,77 & 11,66 & $-0,07$ & $-3,94 \%$ & $-1,76$ & $-15,06 \%$ \\
\hline Luxembourg & 1,81 & 13,20 & 1,73 & 11,43 & $-0,08$ & $-4,34 \%$ & $-1,77$ & $-15,50 \%$ \\
\hline Malta & 1,79 & 13,10 & 1,72 & 11,32 & $-0,08$ & $-4,52 \%$ & $-1,78$ & $-15,70 \%$ \\
\hline
\end{tabular}

Source: Own calculations. Data on the population based on Council Decision (EU, Euratom) 2015/2393 of 8 December 2015 Amending the Council's Rules of Procedure.

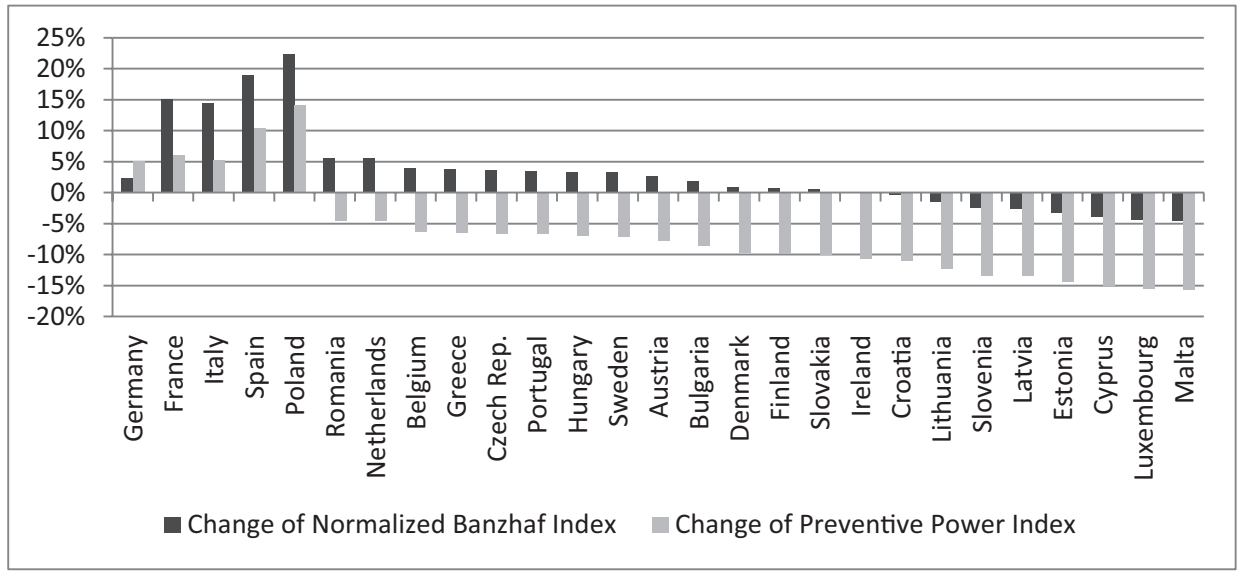

Chart 1. Change in the voting power of the Member States when adopting decisions by the qualified majority of votes (measured by the Normalized Banzhaf Index and the Preventive Power Index) following the UK's withdrawal from the EU

Source: Own calculations.

On the other hand, in the case of the ability to block decisions measured by the Preventive Power Index, only Germany, France, Italy, Spain and Poland increase their possibilities in this respect, but Berlin's ability to block decisions is clearly much bigger than that of the other countries. 
The UK's withdrawal from the EU does not drastically alter the formal voting power of states in the Council in the case of decisions adopted by a qualified majority of votes. Among the five Member States with the biggest populations, however, in terms of formal voting power, a division into three groups is becoming more and more distinct: Germany - an independent leader, France and Italy forming a group of large states, and Spain and Poland, which can be referred to as the "average+". Poland, in particular, clearly diverges from Germany, France and Italy in this respect. For the government in Warsaw, its formal voting power is far more important than for Berlin or Paris, as the scope and frequency of adopting decisions by qualified majority voting in the Council is increasing, and the extra-formal capacity of Polish authorities to influence the shape of decisions adopted in the EU is relatively lower.

\section{POLAND'S ABILITY TO BUILD SMALL STRICTLY MINIMALLY BLOCKING COALITIONS AFTER BREXIT}

The United Kingdom's withdrawal from the EU will fundamentally change the ability of Member States to create strictly minimally blocking coalitions $s^{4}$. The coefficient of blocking power was used to determine the ability of Member States to build small minimally blocking coalitions. It is defined as the ratio of the number of strictly minimally blocking coalitions containing player $i$ to the number of all strictly minimally blocking coalitions, according to the formula (Sozański, 2014, p. 14):

$$
\gamma(i)=\frac{\sum_{k=k \min }^{k \max } b m, k(\mathrm{i})}{\sum_{k=k \min }^{k \max } b m, k} \cdot 100 \%
$$

where:

$\gamma(i)$ - the blocking power coefficient,

$k$ - the size of a strictly minimally blocking coalition from $k_{\min }$ to $k_{\max }$ members, $b m, k(i)$ - the number of strictly minimally blocking coalitions with a size of $k$ members

containing voter $i$,

- the number of strictly minimally blocking coalitions with a size of $k$ members.

4 A blocking coalition is called strictly minimal when none of its possible sub-coalitions has equal voting power, i.e., it cannot guarantee the blocking of a decision. 
For a priori voting, this coefficient determines the probability that a given state will be a member of a small strictly minimally blocking coalition counting from $k_{\min }$ to $k_{\max }$, and is used primarily to describe the blocking structure for voting games. For example, if for player $i$ the value of this coefficient for a coalition with size $k$ is $\gamma(i)$, this means that the player is a member of $70 \%$ of strictly minimally blocking coalitions with size $k$ possible to create. If voter $i$ does not decide to support the proposed initiative, the number of strictly minimally blocking coalitions counting $k$ members possible to create will decrease by $70 \%$.

The coefficient of blocking power well reflects the specificity of the decisionmaking process in the Council. During the negotiations on the reform of the weighted voting system in the Treaty of Lisbon, the Member States were not so much interested in the ability to build winning coalitions, or in the value of the mathematical indices defining the ability to block a decision, but in the chance for individual states to form a blocking coalition consisting of relatively few members (Moberg, 2014, pp. 66-89). This knowledge helps to answer the two questions often faced by members of the Council: Who should be attracted to a coalition in order to prevent the adoption of decisions unfavourable to us? Which states should be persuaded in order to prevent the creation of a blocking coalition? Forming a blocking coalition consisting of a considerable number of Member States is very difficult, since the European Commission is actively using the capacity to shape the agenda it has (Tallberg, 2006; Pollack, 2003). Decisions in the Council are adopted mainly through negotiation, and the political culture prevailing in the institution stigmatizes acts of blocking decisions by the minority (Novak, 2011, p. 19).

The figures in Table 3 show that in the case of the EU consisting of 28 countries, in terms of the number of combinations of strictly minimally blocking coalitions that can be formed in the Council, and counting from 4 to 6 states. Germany clearly outdistances the other Member States, including France, the second biggest state in terms of population. On the other hand, in the case of countries with a population equal to or less than Austrias, the ability to form four- or five-state blocking coalitions is illusory since it requires gaining the support of at least two or three of the six states with the largest populations, and in particular Germany. In practice, situations in which three out of the six states with the largest populations would be outvoted while adopting a decision in the Council by a qualified majority do not happen. Extremely rare are cases where a decision is adopted against two of the six largest Member States, but they do not deal with issues connected with some important national interest of these 
states (Kleinowski, 2012, pp.42-43). This implies that the influence of the largest members of the Council on adopted decisions is bigger than it would result from their formal voting power, and the convergent position of the majority of them determines the framework within which agreement can be reached.

Table 3. The ability of EU states to form strictly minimally blocking coalitions with a small number of members, while weighting the votes according to the so-called "double majority" system, before and after Brexit

\begin{tabular}{|c|c|c|c|c|c|c|c|c|c|c|c|c|}
\hline \multirow{3}{*}{ State } & \multicolumn{6}{|c|}{ UE 28} & \multicolumn{6}{|c|}{ UE 27} \\
\hline & \multicolumn{2}{|c|}{$k=4$} & \multicolumn{2}{|c|}{$k=5$} & \multicolumn{2}{|c|}{$k=6$} & \multicolumn{2}{|c|}{$k=4$} & \multicolumn{2}{|c|}{$k=5$} & \multicolumn{2}{|c|}{$k=6$} \\
\hline & $\begin{array}{l}b m, \\
k(i)\end{array}$ & $\gamma(i)$ & $\begin{array}{l}b m, \\
k(i)\end{array}$ & $\gamma(i)$ & $\begin{array}{l}b m, \\
k(i)\end{array}$ & $\gamma(i)$ & $\begin{array}{l}b m, \\
k(i)\end{array}$ & $\gamma(i)$ & $\begin{array}{l}b m, \\
k(i)\end{array}$ & $\gamma(i)$ & $\begin{array}{l}b m, \\
k(i)\end{array}$ & $\gamma(i)$ \\
\hline Germany & 215 & $71,7 \%$ & 415 & $64,3 \%$ & 1772 & $67,2 \%$ & 432 & $850 \%$ & 328 & $62,6 \%$ & 1191 & $48,8 \%$ \\
\hline France & 168 & $56,0 \%$ & 280 & $43,4 \%$ & 1020 & $38,7 \%$ & 313 & $61,6 \%$ & 202 & $38,5 \%$ & 1087 & $44,5 \%$ \\
\hline $\begin{array}{c}\text { United } \\
\text { Kingdom }\end{array}$ & 162 & $54,0 \%$ & 262 & $40,6 \%$ & 1017 & $38,6 \%$ & - & - & - & - & - & - \\
\hline Italy & 151 & $50,3 \%$ & 237 & $36,7 \%$ & 901 & $34,2 \%$ & 241 & $47,4 \%$ & 283 & $54,0 \%$ & 917 & $37,6 \%$ \\
\hline Spain & 124 & $41,3 \%$ & 129 & $20,0 \%$ & 576 & $21,9 \%$ & 123 & $24,2 \%$ & 188 & $35,9 \%$ & 1123 & $46,0 \%$ \\
\hline Poland & 90 & $30,0 \%$ & 269 & $41,7 \%$ & 654 & $24,8 \%$ & 114 & $22,4 \%$ & 88 & $16,8 \%$ & 594 & $24,3 \%$ \\
\hline Romania & 22 & $7,3 \%$ & 210 & $32,6 \%$ & 728 & $27,6 \%$ & 69 & $13,6 \%$ & 86 & $16,4 \%$ & 708 & $29,0 \%$ \\
\hline Netherlands & 20 & $6,7 \%$ & 143 & $22,2 \%$ & 811 & $30,8 \%$ & 59 & $11,6 \%$ & 174 & $33,2 \%$ & 578 & $23,7 \%$ \\
\hline Belgium & 15 & $5,0 \%$ & 119 & $18,4 \%$ & 664 & $25,2 \%$ & 52 & $10,2 \%$ & 62 & $11,8 \%$ & 632 & $25,9 \%$ \\
\hline Greece & 14 & $4,7 \%$ & 112 & $17,4 \%$ & 641 & $24,3 \%$ & 50 & $9,8 \%$ & 64 & $12,2 \%$ & 622 & $25,5 \%$ \\
\hline Czech Rep. & 14 & $4,7 \%$ & 121 & $18,8 \%$ & 640 & $24,3 \%$ & 48 & $9,4 \%$ & 90 & $17,2 \%$ & 605 & $24,8 \%$ \\
\hline Portugal & 14 & $4,7 \%$ & 120 & $18,6 \%$ & 632 & $24,0 \%$ & 48 & $9,4 \%$ & 89 & $17,0 \%$ & 600 & $24,6 \%$ \\
\hline Hungary & 14 & $4,7 \%$ & 107 & $16,6 \%$ & 664 & $25,2 \%$ & 47 & $9,3 \%$ & 84 & $16,0 \%$ & 553 & $22,7 \%$ \\
\hline Sweden & 14 & $4,7 \%$ & 107 & $16,6 \%$ & 657 & $24,9 \%$ & 47 & $9,3 \%$ & 84 & $16,0 \%$ & 543 & $22,3 \%$ \\
\hline Austria & 13 & $4,3 \%$ & 99 & $15,3 \%$ & 616 & $23,4 \%$ & 45 & $8,9 \%$ & 82 & $15,6 \%$ & 456 & $18,7 \%$ \\
\hline Bulgaria & 13 & $4,3 \%$ & 78 & $12,1 \%$ & 551 & $20,9 \%$ & 37 & $7,3 \%$ & 110 & $21,0 \%$ & 511 & $20,9 \%$ \\
\hline Denmark & 13 & $4,3 \%$ & 62 & $9,6 \%$ & 444 & $16,9 \%$ & 33 & $6,5 \%$ & 70 & $13,4 \%$ & 564 & $23,1 \%$ \\
\hline Finland & 12 & $4,0 \%$ & 72 & $11,2 \%$ & 420 & $15,9 \%$ & 33 & $6,5 \%$ & 65 & $12,4 \%$ & 562 & $23,0 \%$ \\
\hline Slovakia & 12 & $4,0 \%$ & 72 & $11,2 \%$ & 411 & $15,6 \%$ & 33 & $6,5 \%$ & 64 & $12,2 \%$ & 547 & $22,4 \%$ \\
\hline Ireland & 12 & $4,0 \%$ & 54 & $8,4 \%$ & 425 & $16,1 \%$ & 31 & $6,1 \%$ & 58 & $11,1 \%$ & 475 & $19,5 \%$ \\
\hline Croatia & 12 & $4,0 \%$ & 52 & $8,1 \%$ & 378 & $14,3 \%$ & 30 & $5,9 \%$ & 58 & $11,1 \%$ & 430 & $17,6 \%$ \\
\hline Lithuania & 11 & $3,7 \%$ & 35 & $5,4 \%$ & 300 & $11,4 \%$ & 27 & $5,3 \%$ & 58 & $11,1 \%$ & 326 & $13,4 \%$ \\
\hline Slovenia & 11 & $3,7 \%$ & 22 & $3,4 \%$ & 240 & $9,1 \%$ & 21 & $4,1 \%$ & 61 & $11,6 \%$ & 271 & $11,1 \%$ \\
\hline
\end{tabular}




\begin{tabular}{|c|c|c|c|c|c|c|c|c|c|c|c|c|}
\hline \multirow{3}{*}{ State } & \multicolumn{6}{|c|}{ UE 28} & \multicolumn{6}{|c|}{ UE 27} \\
\hline & \multicolumn{2}{|c|}{$k=4$} & \multicolumn{2}{|c|}{$k=5$} & \multicolumn{2}{|c|}{$k=6$} & \multicolumn{2}{|c|}{$k=4$} & \multicolumn{2}{|c|}{$k=5$} & \multicolumn{2}{|c|}{$k=6$} \\
\hline & $\begin{array}{l}b m, \\
k(i)\end{array}$ & $\gamma(i)$ & $\begin{array}{l}b m, \\
k(i)\end{array}$ & $\gamma(i)$ & $\begin{array}{l}b m, \\
k(i)\end{array}$ & $\gamma(i)$ & $\begin{array}{l}b m, \\
k(i)\end{array}$ & $\gamma(i)$ & $\begin{array}{l}b m, \\
k(i)\end{array}$ & $\gamma(i)$ & $\begin{array}{l}b m, \\
k(i)\end{array}$ & $\gamma(i)$ \\
\hline Latvia & 11 & $3,7 \%$ & 20 & $3,1 \%$ & 236 & $9,0 \%$ & 21 & $4,1 \%$ & 58 & $11,1 \%$ & 256 & $10,5 \%$ \\
\hline Estonia & 11 & $3,7 \%$ & 12 & $1,9 \%$ & 163 & $6,2 \%$ & 20 & $3,9 \%$ & 42 & $8,0 \%$ & 189 & $7,7 \%$ \\
\hline Cyprus & 11 & $3,7 \%$ & 5 & $0,8 \%$ & 122 & $4,6 \%$ & 20 & $3,9 \%$ & 30 & $5,7 \%$ & 138 & $5,7 \%$ \\
\hline Luxembourg & 10 & $3,3 \%$ & 6 & $0,9 \%$ & 74 & $2,8 \%$ & 19 & $3,7 \%$ & 25 & $4,8 \%$ & 89 & $3,6 \%$ \\
\hline Malta & 10 & $3,3 \%$ & 5 & $0,8 \%$ & 53 & $2,0 \%$ & 19 & $3,7 \%$ & 17 & $3,2 \%$ & 73 & $3,0 \%$ \\
\hline$b m, k$ & \multicolumn{2}{|c|}{300} & \multicolumn{2}{|c|}{645} & \multicolumn{2}{|c|}{2635} & \multicolumn{2}{|c|}{508} & \multicolumn{2}{|c|}{524} & \multicolumn{2}{|c|}{2440} \\
\hline
\end{tabular}

Source: Own calculations.

As a result of Brexit, the ability of Member States to build small strictly minimally blocking coalitions is changing. In particular, it will be more difficult to block decisions against the position of the German-French tandem, and it may be crucial to win Italy for a coalition in such a case. At the same time, blocking a decision enjoying the support of the three members of the Council with the largest populations will become difficult, as it will require the formation of a blocking coalition of at least eight states, and in practice probably even more. Following the United Kingdom's withdrawal from the EU, the Netherlands and Bulgaria will become much more valuable allies when it comes to building a 5-state blocking coalition. The importance of Spain has relatively decreased in the case of a blocking coalition consisting of 4 members of the Council, but increased for a coalition of 5 or 6 Member States. The most unfavourable change has occurred for Poland, whose ability to co-create small strictly minimally blocking coalitions diminishes radically and is by far divergent from the possibilities that Germany, France, Italy and Spain have in this respect.

Poland's ability to form small strictly minimally blocking coalitions will be even smaller in a situation when the government in Warsaw is in opposition to the largest Member States. Simulating a vote in such a case requires a departure from the assumption that each member of the Council is equally likely to cast a vote both "for" and "against" an initiative, and that individual states take their positions independently of one another. As indicated in Table 4, if Poland is in opposition to France or Germany, or both, it is crucial to win the support of two EU countries with a population of over 30 million to create a blocking coalition with a small number of members. As a consequence, the lack of Great 
Britain as a potential coalition member significantly limits Poland's ability to create small blocking coalitions, particularly in the case of coordinating activities by the governments in Paris and Berlin. This is all the more important because the threat of raising an objection by two large Member States, in the case of decisions adopted by a qualified majority, is usually sufficient to obtain significant concessions from the other partners. However, it is doubtful whether a coalition of Poland and Spain has such an ability.

Table 4. Poland's ability to build strictly minimally blocking coalitions in opposition to selected Member States after leaving the EU by the United Kingdom ${ }^{5}$

\begin{tabular}{|c|c|c|c|c|c|c|}
\hline \multirow{2}{*}{\multicolumn{3}{|c|}{$\begin{array}{l}\text { Description of strictly mi- } \\
\text { nimally blocking coalitions } \\
\text { with the participation of } \\
\text { Poland }\end{array}$}} & \multicolumn{4}{|c|}{ Poland in opposition to: } \\
\hline & & & Germany & France & $\begin{array}{l}\text { Germany and } \\
\text { France }\end{array}$ & $\begin{array}{c}\text { Germany, } \\
\text { France and Italy }\end{array}$ \\
\hline \multicolumn{3}{|c|}{$\begin{array}{l}\text { Minimum number of states } \\
\text { in a blocking coalition }\end{array}$} & 4 & 4 & 4 & 8 \\
\hline \multirow{3}{*}{$\begin{array}{l}\text { The number of } \\
\text { strictly minimally } \\
\text { blocking coalitions } \\
\text { consisting of k } \\
\text { members }\end{array}$} & \multirow{3}{*}{$\mathrm{k}$} & 4 & 44 & 54 & 8 & $\mathrm{x}$ \\
\hline & & 5 & 41 & 72 & 25 & $\mathrm{x}$ \\
\hline & & 6 & 118 & 521 & 45 & $\mathrm{x}$ \\
\hline \multicolumn{3}{|c|}{$\begin{array}{l}\text { States necessary to form } \\
\text { a coalition }\end{array}$} & $\mathrm{x}$ & $\mathrm{x}$ & Italy, Spain & $\begin{array}{l}\text { Spain, the } \\
\text { Netherlands }\end{array}$ \\
\hline \multicolumn{3}{|c|}{$\begin{array}{l}\text { Key states for the creation } \\
\text { of a coalition }\end{array}$} & $\begin{array}{l}\text { France, } \\
\text { Italy, Spain, } \\
\text { Romania, the } \\
\text { Netherlands }\end{array}$ & $\begin{array}{l}\text { Germany, } \\
\text { Italy, Spain, } \\
\text { Romania, } \\
\text { the } \\
\text { Netherlands }\end{array}$ & $\begin{array}{l}\text { Romania, the } \\
\text { Netherlands, } \\
\text { Belgium, } \\
\text { Greece, the Czech } \\
\text { Republic, Portugal, } \\
\text { Hungary, Sweden, } \\
\text { Austria, Bulgaria }\end{array}$ & $\begin{array}{l}\text { the Netherlands, } \\
\text { Romania, Belgium, } \\
\text { Greece, the Czech } \\
\text { Republic, Portugal, } \\
\text { Hungary, Sweden, } \\
\text { Austria, Bulgaria }\end{array}$ \\
\hline \multirow{3}{*}{$\begin{array}{l}\text { Poland's share in } \\
\text { the number of } \\
\text { strictly minimally } \\
\text { blocking coalitions } \\
\text { with k members }\end{array}$} & \multirow{3}{*}{$\mathrm{k}$} & 4 & $10,84 \%$ & $17,59 \%$ & $3,49 \%$ & $\mathrm{X}$ \\
\hline & & 5 & $12,73 \%$ & $27,91 \%$ & $43,10 \%$ & $\mathrm{X}$ \\
\hline & & 6 & $14,17 \%$ & $33,94 \%$ & $66,18 \%$ & $\mathrm{X}$ \\
\hline
\end{tabular}

Source: Own calculations.

5 In the carried out simulations, it was assumed that Poland did not support an initiative. In turn, either Germany or France, or one of the coalitions: Germany-France, Germany-France-Italy, Italy-Spain, would opt for it. In the case of the other members of the Council, it was assumed that casting a vote both "for" and "against" an initiative would be equally likely. 
It should also be borne in mind that the position of the government in Warsaw and that of the Mediterranean states on many issues may be fundamentally different. This is evident even in the case of the migration crisis, relations with the Russian Federation, and in the future probably with regard to the expenditures on the implementation of the cohesion policy in the European Union. The traditional instability of Italian governments, as well as the problems confronting this country's economy, may have a negative impact on the durability of strictly minimally blocking coalitions based on that state, especially over a period of more than a few months. It must be borne in mind that already during the $7^{\text {th }}$ term of office of the European Parliament, even in the case of early agreement in the first reading under the ordinary legislative procedure, the average time needed to enact a legislative act was 17 months. If the act was adopted at its second reading, the time of proceeding was lengthened to an average of 32 months (European Parliament, 2015).

In the situation where Poland will be trying to form a blocking coalition in opposition to France and Germany, Italy becomes a key partner without which no strictly minimally blocking coalition of seven or fewer states can be formed. It is also very unlikely to create a blocking coalition of eight members of the Council without this state.

The successful and effective coordination of positions in the Council by the trio of Ventotene would in practice lead to the domination of the decisionmaking process by Germany, France and Italy. Adopting a decision against the will of these states would require the creation of a winning coalition of all 24 other Member States, which should be considered very unlikely. Consequently, a coherent position presented by Germany, France and Italy will determine the area of possible agreement in the Council, which the European Commission would have to take into account when presenting a new legislative initiative.

\section{SUMMARY}

The conducted analysis confirms the truthfulness of the research hypotheses put forward at the beginning. The new legal framework for European statistics, which includes in the population of members of the Council non-citizens of these countries, including non-EU citizens, will lead to the strengthening of the voting power of the Member States with high positive net migration. In particular, the largest states, namely Germany, France, the United Kingdom and 
Spain, are beneficiaries of such a solution as low-population countries build their formal voting power in the Council primarily on the basis of the criterion of the majority of states. The above solution also creates the illusion that the introduction of the so-called double majority system increases the democratic legitimacy of decisions adopted in the European Union.

After Brexit, the voting power (measured by the NBI) of the six states with the largest populations will have increased in the double majority system. In this respect, Poland's voting power is changing, as it is the case with the other Member States of this group. Increasing the ability of the government in Warsaw to block decisions (as measured by the PPI) is illusory because, in practice, Poland's ability to create small blocking coalitions is decreasing.

After the United Kingdom's withdrawal from the European Union, Poland's ability to form strictly minimally blocking coalitions particularly in opposition to the coalitions of Germany and France, or Germany, France and Italy, will be considerably reduced. Especially in the latter case, the permanent and effective coordination of the position presented in the Council by the trio of Ventotene could lead to the domination of the decision-making process in the institution by them.

In light of the results of the conducted research, it can be concluded that the United Kingdom's withdrawal from the European Union, and the introduction of a new legal framework for European statistics, will have a negative impact on Poland's formal voting power in the Council.

\section{REFERENCES:}

Banzhaf, F. (1965). Weighted Voting Does Not Work: A Mathematical Analysis. Rutgers Law Review, 19, 317-343.

Coleman, J.S. (1971). Control of Collectivities and the Power of a Collectivity to Act. In: B. Lieberman (ed.), Social Choice (pp. 269-300). London: Gordon and Breach; reprint: Coleman, J.S. (1986). Individual Interests and Collective Action: Selected Essays. London: Cambridge University.

Consolidated Version of the Treaty on the European Union. Official Journal of the European Union, C 202, 07.06.2016.

Consolidated Version of the Treaty on the Functioning of the European Union. Official Journal of the European Union, C 202, 07.06.2016.

Council Decision (EU, Euratom) 2015/2393 of 8 December 2015 Amending the Council's Rules of Procedure. Official Journal of the European Union, L 332, 18.12.2015. 
European Parliament (2015). Activity Report on Codecision and Conciliation 14 July

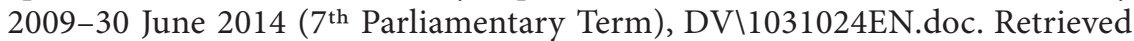
from: http://www.europarl.europa.eu/code/information/activity_reports/activity_report_2009_2014_en.pdf.

Kleinowski, M. (2012). Konsensualne negocjacje czy głosowanie, kontestowanie aktów prawnych w Radzie UE. Studia Europejskie, 4, 27-50.

Kleinowski, M. (2013). Konsensualne podejmowanie decyzji jako wartość dla państw członkowskich w Radzie i Radzie Europejskiej. Społeczeństwo i Polityka, 4, 15-29.

Kleinowski, M. (2014). Siła państw w Unii Europejskiej. Formalnoprawne wyznaczniki sity państw w Radzie UE i Radzie Europejskiej. Toruń: Wydawnictwo Adam Marszałek.

Laruelle, A., \& Valenciano, F. (2005). Assessing Success and Decisiveness in Voting Situations. Social Choice and Welfare, 24(1), 171-197.

Miller, V., \& Taylor, C. (2008). The Treaty of Lisbon: Amendments to the Treaty on European Union. UK House of Commons Library Research Paper, 08/09, 1-85.

Moberg, A. (2014). The Weight of Nations: Four Papers on the Institutional Negotiations in the EU 1996-2007. Malmö: Tryck.

Novak, S. (2011). Qualified Majority Voting from the Single European Act to Present Day: An Unexpected Permanence. Studies \& Research, 88, 1-34.

Pollack, M.A. (2003). The Engines of European Integration: Delegation, Agency and Agenda Setting in the EU. Oxford: Oxford University Press.

Regulation (EU) No 1260/2013 of the European Parliament and of the Council of 20 November 2013 on European Demographic Statistics. Official Journal of the European Union, L 330, 10.12.2013.

Sozański, T. (2014). The Conception of Blocking Power as a Key to the Understanding of the History of Designing Voting Systems for the EU Council. Decyzje, 22, 5-46.

Tallberg, J. (2006). Leadership and Negotiation in the European Union. New York: Cambridge University Press. 